\title{
Insurance Fraud and the Role of the Civil Law
}

\author{
P. J. Rawlings and J. P Lowry*
}

Keywords: fraudulent insurance claims; fraud in insurance claims settlements; Versloot Dredging BV v HDI-Gerling Industrie Versicherung (The DC Merwestone); Hayward v Zurich Insurance Co plc; the Criminal Justice and Courts Act 2015; the Insurance Act 2015; the civil law; deterrence

\section{THE FRAUDULENT CLAIMS RULE}

As a common law subject, the development of insurance law depends on the happenchance of litigation, which is problematic since insurance disputes rarely end in court - consumers prefer the Financial Ombudsman and commercial parties use arbitration. This means that two Supreme Court appeals within days of one another constitute riches. Both concerned fraud: in one, a lie was used in connection with a legitimate claim, ${ }^{1}$ and in the other it was used to increase the settlement paid by the insurers. $^{2}$ But these cases also draw attention to the broader issue of the proper province of the civil law.

Typically, insurance fraud occurs either when a proposal is made for cover, or, as in these cases, when there is a claim. ${ }^{3}$ There is fraud if the claimant knowingly, or recklessly, claims for a loss that has not occurred or exaggerates its amount, or conceals some circumstance that might provide the insurers with a defence to the claim. ${ }^{4}$ The other area of claims fraud is where a third party dishonestly alleges a loss suffered as the result of the policyholder's breach of duty (such as a workplace injury or road accident) and this triggers a claim under a liability policy. ${ }^{5}$ Finally, there is the situation where the insurers suspect but cannot prove fraud and so agree to settle only to discover sometime later sufficient evidence of the fraud.

\footnotetext{
* Respectively, The Roy Goode Professor of Commercial Law, Insurance Law Institute, Centre for Commercial Law Studies, Queen Mary University of London and Emeritus Professor of Commercial Law, Faculty of Laws, UCL.

${ }^{1}$ Versloot Dredging BV v HDI-Gerling Industrie Versicherung (The DC Merwestone) [2016] UKSC 45.

${ }^{2}$ Hayward $v$ Zurich Insurance Co plc [2016] UKSC 48.

${ }^{3}$ Pre-contractual fraud is often only discovered when there is a claim, and insurers, who suspect claim fraud but lack evidence, may seek other reasons for refusing payment, such as breach of the precontractual duty of fair presentation or lack of insurable interest: Western Trading Ltd v Great Lakes Reinsurance (UK) Ltd [2015] EWHC103 (QB), [60]. Though in the case of the latter defence, the courts have long been ill disposed towards insurers who seek to rely on it where they are fully cognisant of the risk: see, Stock v Inglis (1884) 12 QBD 564, 571, Lord Brett MR.

${ }^{4}$ Aviva Insurance Ltd v Brown [2011] EWHC 362 (QB) at [64].

${ }^{5}$ See A. Bugra and R. Merkin, '"Fraud" and Fraudulent Claims' (2012) 125 Journal of the British Insurance Law Association 3. See further, J. Davey and K. Richards, 'Deterrence, Human Rights and Illegality: The Forfeiture Rule in Insurance Contract Law' [2015] LMCLQ 314; and P.J. Rawlings and J.P. Lowry, 'Insurance Fraud: The "Convoluted and Confused" State of the Law' (2016) 132 LQR 96. See also, B. Soyer, Marine Insurance Fraud (Abingdon: Informa, 2014).
} 
Insurance is a contract of indemnity, which means the insurers are liable only for actual losses. Under the fraudulent claims rule, however, if there has been fraud by the policyholder, the insurers can refuse payment of the entire claim, including genuine losses, ${ }^{6}$ recoup payments relating to that claim, ${ }^{7}$ terminate the contract and retain the premium, although there remains liability for pre-fraud claims. ${ }^{8}$ Fraud will also taint the rights of an innocent joint insured. ${ }^{9}$ On the other hand, this rule did not apply to a dishonest third party, such as the victim of a workplace or road accident, which meant he or she could maintain the claim (nominally against the tortfeasor but in practice against the tortfeasor's insurers) for genuine losses. As will be seen later, the Criminal Justice and Courts Act 2015, in effect, now extends the rule to such claimants. $^{10}$

The scope of the fraudulent claims rule was discussed in Agapitos $v$ Agnew (The Aegeon) (No. 1). ${ }^{11}$ Mance LJ, obiter, thought it included the use of a fraudulent device, such as a forged receipt, to support a genuine claim. At first instance, Toulson $\mathrm{J}$ had rejected this extension of the fraudulent claims rule, but Mance LJ disagreed. He remarked that, while the principal part of the fraudulent claims rule had been settled in the nineteenth century, ' $[t]$ he proper approach to the use of fraudulent devices or means is much freer from authority', ${ }^{2}$ and he went on to observe:

Tentatively, I would suggest that the courts should only apply the fraudulent claim rule to the use of fraudulent devices or means which would, if believed, have tended, objectively but prior to any final determination at trial of the parties' rights, to yield a not insignificant improvement in the insured's prospects - whether they be prospects of obtaining a settlement, or a better settlement, or of winning at trial. ${ }^{13}$

The lie had to be substantial and 'directly be related to and intended to promote the claim', ${ }^{14}$ but he did not think it necessary to show that the insurers had relied on the fraud.

\section{THE VERSLOOT DREDGING CASE}

The fraudulent devices rule made relatively few appearances in the courts in the decade after The Aegeon, ${ }^{15}$ until Versloot Dredging BV v HDI-Gerling Industrie Versicherung (The DC Merwestone). ${ }^{16}$ Shortly after leaving Klaipeda in Lithuania,

\footnotetext{
${ }^{6} \mathrm{n} 3$ above.

${ }^{7}$ For an illustration of the severity of this, see Aviva Insurance Ltd v Brown [2011] EWHC 362 (QB).

${ }^{8}$ Insurance Act 2015, s 12.

${ }^{9}$ Direct Line Insurance Plc v Khan [2001] EWCA Civ 1794. But not co-insureds: Parker v NFU Mutual Insurance Society Ltd [2012] EWHC 2156 (Comm).

${ }^{10}$ Criminal Justice and Courts Act 2015, s 57.

${ }^{11}$ [2002] EWCA Civ 247.

12 ibid at [45].

13 ibid at [38].

14 ibid at [37].

${ }^{15}$ For example, Sharon's Bakery (Europe) Ltd v Axa Insurance Plc [2011] EWHC 210 (Comm) at [76][77]

${ }^{16}$ [2013] EWHC 1666 (Comm); [2014] EWCA Civ 1349; [2016] UKSC 45. Note the criticism of such a rule in Royal Boskalis Westminster NV v Mountain [1999] QB 674.
} 
water flooded the engine room of the 'DC Merwestone', damaging the engine and causing losses amounting to $€ 3.214$ million. The incident was the result of a number of factors: the crew's negligence in failing to close the sea inlet valve of the fire pump and drain the system, after using the hoses to clear ice; the damage to the emergency fire system pump casing and filter as a result seawater freezing inside them soon after sailing from port; the earlier negligence of contractors, who had not sealed the engine room bulkheads after undertaking work in the area; and defects in the pumping system which meant it could not cope with the ingress of water. The insurers instructed Ince \& Co, solicitors, to investigate. Mr Chris Kornet, for the owners, developed a theory that the bilge alarm had sounded, but the crew did not respond because of the rolling of the ship in heavy seas. In a letter dated 21 April, he asserted that this was what occurred. At first instance, Popplewell J determined that this was speculation by Kornet, even though he genuinely believed it to be plausible. When he wrote the letter no members of the crew had given this explanation, and he had no reason to believe that any would. His reason for telling the untruth was frustration at the insurers' delay in dealing with the claim. The cause of the flooding was unclear, and he thought that attaching blame to the crew would reinforce the claim and speed payment. Moreover, he was concerned that uncertainty about the cause might lead the insurers to focus on the defective condition of the ship, and that, in turn, might lead to blame attaching to the owners, and mean the insurers were not liable under the policy terms. Subsequently, in a letter dated 27 July Kornet repeated the earlier explanation, but this time he did so in the belief that the ship's master had confirmed it.

As the facts emerged during the trial, it became clear that the lie was irrelevant. Popplewell J held the loss had been proximately caused by the ingress of seawater through the sea inlet valve during the voyage, which was a peril of the seas and, therefore, covered. He also rejected the argument made by the insurers that the owners had sent the ship to sea knowing of the defective pumps, which would have been a breach of warranty, because he concluded that at the time of sailing the owners had not known of the problem. This meant there was a valid claim for $€ 3.214$ million, but, with manifest reluctance, the judge felt bound by The Aegeon to conclude that the insurers were not liable because Kornet's response to the solicitor's questions in the letter of 21 April (but not the July letter) constituted a fraudulent device.

By one of those curious coincidences, before his appointment to the bench Popplewell $\mathrm{J}$ had been counsel in The Aegeon where he argued for the fraudulent devices rule. But as a judge he attacked it as visiting 'disproportionately harsh and unjust consequences upon an assured in favour of an undeserving insurer. ${ }^{17} \mathrm{He}$ said of Kornet's behaviour, 'In a scale of culpability... this was at the low end. ${ }^{18}$ It was not carefully planned, it was told on one occasion and not repeated at the trial, and it was used to support a theory which K genuinely held. Moreover, the crew had been made

\footnotetext{
${ }^{17} \mathrm{ibid}$ at [167].

${ }^{18} \mathrm{ibid}$ at [225].
} 
available to the insurers' solicitor, allowing them to undertake their own inquiry. 'To be deprived of a valid claim of some $€ 3.2 \mathrm{~m}$ as a result of such reckless untruth is, in my view, a disproportionately harsh sanction. ${ }^{19}$ Popplewell $\mathrm{J}$ would have favoured a rule that required 'a sufficiently close connection between the fraudulent device and the valid claim to make it just and proportionate that the valid claim should be forfeit. $^{20}$

The Court of Appeal took a different view. Christopher Clarke LJ agreed that the fraudulent devices rule was draconian but believed it necessary as a 'deterrent to the deception of insurers who, in the nature of things, will have no, or very little, knowledge of the incident'. ${ }^{21}$ Removing the rule would encourage lying because the insured would have a one-way bet in that there would be an illegitimate gain if the lie succeeded and no loss if it failed. In any event, he noted that the Supreme Court had approved the fraudulent device rule (albeit in obiter) in Fairclough Homes Ltd v Summers. ${ }^{22}$

\section{Versloot Dredging in the Supreme Court}

The Supreme Court reversed the Court of Appeal by a majority (4-1), ruling against the fraudulent devices rule by holding that the use of fraudulent devices does not amount to a fraudulent claim and so the claim is not forfeit. The consequence is that there is no longer a remedy where the insured has harnessed a fraudulent device to support its claim. While the appeal concerned a marine policy, Lord Hughes regarded its conclusions as applying to all insurance. ${ }^{23}$ The abolition of the rule is significant. Popplewell J had only argued for a materiality test that would have 'permitted the court to look at whether it was just and proportionate to deprive the assured of his substantive rights'. ${ }^{24}$

The majority took the view that this area was ready for (re)evaluation. Lord Hughes thought there was little support in the cases for the rule. The authorities were 'scanty and equivocal', ${ }^{25}$ and the issue had not been properly argued since The Aegeon, because most - or perhaps all - of the cases commonly believed to be about fraudulent devices were, in his opinion, really either fraudulent claims or breaches of the pre-contractual duty of disclosure. ${ }^{26}$ Lord Sumption noted that the fraudulent device rule had been applied by the Privy Council and endorsed by the Supreme Court, ${ }^{27}$ but thought there had been 'considerable judicial misgivings'. ${ }^{28}$ On the other

\footnotetext{
19 ibid.

${ }^{20}$ ibid at [177].

${ }^{21} \mathrm{n} 16$ above, at [75]. Interestingly, Christopher Clarke J (as he then was) and Popplewell J were among six judges who criticised forfeiture in fraud: Law Commissions of England and Wales and Scotland, Insurance Contract Law: Business Disclosure; Warranties; Insurers' Remedies for Fraudulent Claims; and Late Payment, (Law Com. No 353/Scots Law Com No 238), at para.21.16, available at http://www.lawcom.gov.uk/wp-content/uploads/2015/03/lc353_insurance-contract-law.pdf (last accessed 10 November 2016).

${ }^{22}$ [2012] UKSC 26, discussed below: see text to notes 54-64.

${ }^{23}$ ibid at [52]. It is noteworthy that the decision of the Supreme Court aligns the law with that of Australia and the USA.

${ }^{24} \mathrm{n} 16$ above, at [171].

$25 \mathrm{n} 1$ above, at [81].

${ }^{26}$ But see, Sharon's Bakery (Europe) Ltd v Axa Insurance Plc n 15 above, at [76]-[77].

${ }^{27}$ Stemson v AMP General Insurance (NZ) Ltd. [2006] UKPC 30 at [35]-[36]; Summers v Fairclough Homes Ltd $\mathrm{n} 22$ above, at [29].
} 
hand, in an opinion that shows the difficulties facing the common lawyer, Lord Mance, who unsurprisingly dissented, read the authorities rather differently, seeing in them 'long-standing if limited authority'. ${ }^{29}$

Lord Sumption signalled his intention by preferring 'collateral lie' to 'fraudulent device' and defining it as 'a lie which turns out when the facts are found to have no relevance to the insured's right to recover'. ${ }^{30} \mathrm{He}$ accepted the fraudulent claims rule, but said, 'there are principled limits to the role which a claimant's immorality [here, the telling of the lie] can play in defeating his legitimate civil claims'. ${ }^{31}$ Those limits were breached by the proposition that the fraudulent claims rule included collateral lies.

The insurance contract is a contract of indemnity under which the insurers promise to hold the indemnified person harmless against the loss, so that 'once the loss is suffered... the indemnifier is in breach of contract for having failed to hold the indemnified person harmless against the relevant loss' ${ }^{32}$ Does the use of a fraudulent device mean that an existing liability should be removed? Lord Sumption thought not. For him, there was a distinction between a fraudulently exaggerated claim, where the insured sought to obtain something to which there was no entitlement, and a collateral lie, where there was a genuine entitlement. In the latter situation, 'the lie is dishonest, but the claim is not. ${ }^{33}$

He rejected Christopher Clarke LJ's argument that the collateral lie might lead the insurers to make irrelevant inquiries, pointing out that the objective of the fraudulent claims rule was to deter dishonestly exaggerated claims, not save the insurers from wasted effort. He also dismissed the idea that without the fraudulent devices rule the insured would be encouraged to lie by the one-way bet because, as the claim was genuine, the insured gained nothing and the insurers lost nothing.

Lord Hughes observed that a collateral lie might still carry consequences, even if not those set out in The Aegeon. It could constitute contempt of court, although this is hard to see where the lie is irrelevant, and, as he admitted, prosecutions are rare. Similarly, he confessed that the possibility of the insurers obtaining damages for deceit was 'comparatively remote'. ${ }^{34}$ The policyholder might be required to disclose the lie in future applications for cover, which would make it difficult or more expensive to obtain cover, but, again, this seems unlikely if the lie was collateral so that the claim was not refused for fraud. ${ }^{35}$ More likely was his suggestion that the policyholder would find it difficult to convince the insurers or the court even when telling the truth about the claim. This may result in the insured being unable to prove the loss, and have an impact on the ability to obtain cover in the future from other insurers if they ask whether or not any claims have been refused.

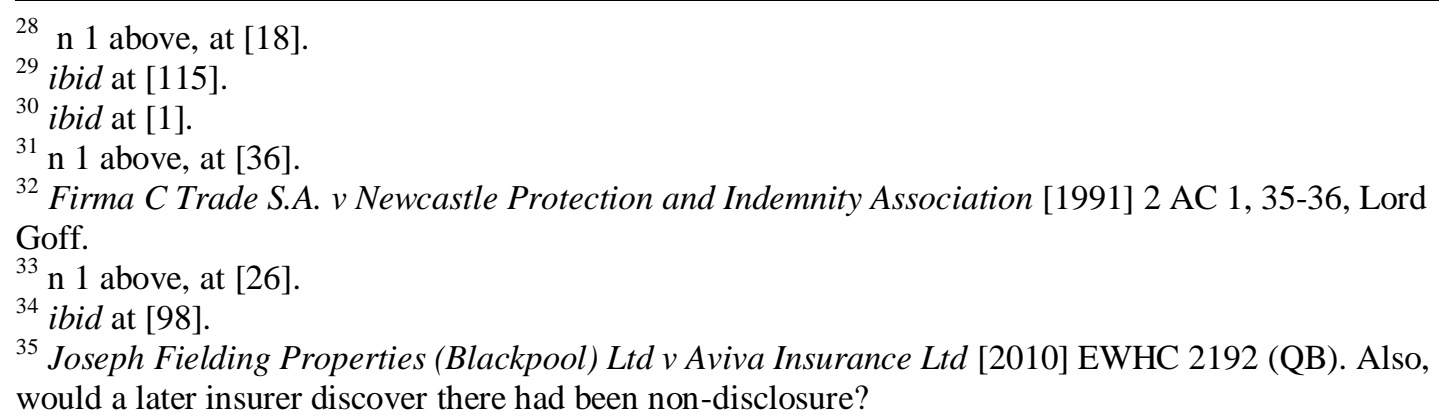


Counsel for the insurers in Versloot drew a parallel with pre-contractual disclosure, and suggested a connection between the lie and the claim existed where the lie was material to the merits of the claim as they appeared at the time it was uttered, even if all the facts were not known and, as in this case, turned out quite differently. Again, Lord Sumption disagreed. He thought there was a fundamental difference between the pre-contractual and the claims stages. The insurers have unlimited discretion when deciding whether to accept a risk and so needs all the facts, whereas the insurers are obliged to pay a claim that is covered by the policy and that liability depends on the facts as they were at the time of the loss, not as they appeared when the claim was made.

Not surprisingly, Lord Mance dissented. Whereas the majority regarded the objective of the fraudulent claims rule as deterring fraudulent claims, he saw it more broadly as encouraging integrity in the claims process. He, therefore, did not distinguish fraudulent devices from dishonestly exaggerated claims - the lie made the genuine claim fraudulent.

In the end the appeal turned on the majority's view that forfeiture of the claim for a collateral lie was unjustified. According to Lord Toulson, 'the court must be guided by its own sense of what is just and appropriate. When all is said and done, that is the critical question on which the court is divided. ${ }^{, 36}$ Lord Sumption thought that, "the moral character of the insured's lie is in no way mitigated by the fact that it turns out to have been unnecessary. But there are principled limits to the role which a claimant's immorality can play in defeating his legitimate civil claims. ${ }^{37}$ For Lord Hughes extending the fraudulent claims rule was 'too large a sledgehammer for the nut involved.' 38

there is plainly a difference of quality between the insured who deals fraudulently with his insurer in an attempt to gain something to which he is not entitled, and the insured who dishonestly gilds the lily with a lie or falsified evidence, but stands thereby to obtain nothing more than was his legal due. ${ }^{39}$

It is interesting to note that the Supreme Court's view that the insurers must pay in circumstances where the only reason not to do so is collateral to the claim echoes the approach taken by the Law Commissions in what is now section 11 of the Insurance Act 2015. As will be seen later, this provides that where the aim of a policy term is to reduce the insurers' risk and the term is breached, the insurers remain liable if the insured shows that the breach did not increase the risk of the loss that occurred.

Of course, the facts in Versloot occurred before the Insurance Act 2015 came into effect on 12 August 2016. This statute deals only with remedies for fraudulent claims (s.12), but leaves the definition of that term to the common law, which means it does not include fraudulent devices. At common law it was unclear whether the insurers could terminate the contract and the effect on genuine claims arising after the fraud

\footnotetext{
${ }^{36} \mathrm{n} 1$ above, at [109], Lord Toulson.

${ }^{37} \mathrm{ibid}$ at [36].

${ }_{38}^{38}$ ibid at [100].

${ }^{39} \mathrm{ibid}$.
} 
but before its discovery. These issues were not addressed in Versloot, but it is likely that section 12, broadly, reflects the common law. Under this provision the insurers are not liable for the fraudulent claim (including genuine losses), may recover payments in respect of the claim, and can terminate the contract retrospectively from the time of the fraud, removing liability for subsequent genuine claims but not for those that arose before the fraud and were not connected to it. ${ }^{40}$ The act also provides that where a fraudulent claim is made in group insurance, section 12 applies as if the cover were provided under an individual policy between the insurers and the fraudulent claimant, so that the insurers' rights under section 12 can only be exercised in relation to the cover provided for the fraudulent claimant and without any effect on anyone else (s.13(2)).

\section{MIGHT THE FRAUDULENT CLAIMS RULE RETURN?}

The judgment has received mixed reviews. There has been praise for the removal of a rule that some regarded as difficult to apply and harsh, but insurers, who feel besieged by fraudulent claims, have tended to be critical. Much of the criticism is based on a continued belief that the collateral lie taints the claim, irrespective of its original merits: 'an insured that lies may end up with his claim being paid without having genuinely produced that evidence. ${ }^{41}$ James Dalton, of the Association of British Insurers, thought the decision 'a blow for honest customers', which 'flies in the face of the work that the insurance industry and Government have been doing to crack down on the cheats and fraudsters. ${ }^{, 2}$ In a rather familiar argument, he suggested premiums might increase because of the additional time taken to investigate claims, but his main concern was that 'this decision sends consumers completely the wrong message: that lying to an insurer is somehow okay. ${ }^{43}$

Some difficulties do seem to arise from the decision. The lie is only collateral if it does not relate to the insurers' liability under the policy as this emerges when the facts are discovered, irrespective of the position at the time of the claim, but it will be difficult for the insurers to know whether the lie is collateral when most claims are settled without litigation - the fraudulent devices rule was simpler in this context because it only required proof of the lie. This may be exacerbated by the term implied into insurance contracts under the Enterprise Act 2016 which requires insurers to pay claims 'within a reasonable time'. ${ }^{44}$

But the impact of the decision on practice may have been overstated. It is for the insured to show that a loss has occurred and insurers will continue to refuse or reduce payments where a lie (irrespective of its relevance) casts doubts on the accuracy of

\footnotetext{
${ }^{40}$ See further, R. Merkin and O. Gürses 'The Insurance Act 2015: Rebalancing the Interests of Insurer and Assured' (2015) 78(6) MLR 1004, 1022.

${ }^{41}$ Clyde \& Co, 'Fraudulent Devices' (2016) at http://www.clydeco.com/blog/insurancehub/article/fraudulent-devices-versloot-v-hdi-gerling-supreme-court (last visited 6 October 2016).

${ }^{42}$ J. Dalton, 'ABI response to supreme court ruling: 'A blow for honest customers', 20 July 2016 at https://www.abi.org.uk/News/News-releases/2016/07/ABI-response-to-supreme-court-ruling-inflatingthe-value-of-a-claim-still-remains-fraud (last accessed 7 October 2016).

${ }^{43}$ J. Dalton, 'Lies Are Lies: Supreme Court Ruling Sends Out The Wrong Message To Customers', 27 July 2016 at http://blog.abi.org.uk/2016/07/lies-are-lies-supreme-court-ruling-sends-out-the-wrongmessage-to-customers/ (last accessed 7 October 2016).

${ }^{44}$ Insurance Act 2015, s 13A (inserted by Enterprise Act 2016, s 28(1)).
} 
things the insured has said about the claim. Moreover, the critics forget that the uncertainty as to how the facts might be viewed by a court also operates on the honest insured and may pressure them to settle for a lower amount than the genuine loss. ${ }^{45}$

Nevertheless, Lord Mance suggested that insurers might think about reintroducing the fraudulent devices rule:

In the light of the majority judgment, insurers will no doubt be advised about whatever may be the potential merits of making express in future whatever understanding they have, or action they may wish to take, regarding the effect of fraudulent devices, as and when such are discovered to have been used by an insured during the claims process. ${ }^{46}$

Indeed, as a result of Popplewell J's attack, some lawyers had already begun to advise insurers to insert such clauses.

How is this to be achieved? At present not all policies contain terms excluding liability where there is a fraudulent device, and those that do reveal some drafting problems in the wake of Versloot. There is a condition precedent to liability in the Institute Hull Clauses 2003, 45.3, which states the assured shall not:

knowingly or recklessly... mislead or attempt to mislead the Underwriters in the proper consideration of a claim or the settlement thereof by relying on any evidence which is false... [or] conceal any circumstance or matter from the Underwriters material to the proper consideration of a claim or a defence to such a claim.

It cannot be argued that a collateral lie is material to a claim, and it seems implausible to suggest that the words 'proper consideration of a claim' revive the fraudulent devices rule. Another form of such a clause is, 'If your claim is in any way dishonest or exaggerated we will not pay any benefit'. ${ }^{47}$ This would not seem to allow refusal of a claim for a collateral lie since 'in any way dishonest' refers to the claim and the claim is legitimate. In Joseph Fielding Properties (Blackpool) Ltd v Aviva Insurance $L t d{ }^{48}$ the policy read: 'We will at our option avoid the policy from the inception of this insurance or from the date of the claim or alleged claim or avoid the claim... [if] a false declaration or statement is made or fraudulent device put forward in support of a claim. ${ }^{49}$ But this clause was titled 'Fraud' and is presumably confined to fraudulent claims since 'fraudulent device' has been emptied of meaning, or, at least, requires some definition to be provided by the policy which does not remove liability for covered losses. The same interpretation might be placed on a clause under which

\footnotetext{
${ }^{45}$ Criticism of insurers' practices in relation to claims settlements following road traffic accidents eventually led the Association of British Insurers to issue of a voluntary code of practice (2014), although the real trigger appears to have been the government's reduction in fixed claimant costs for low-value road traffic claims: https://www.abi.org.uk/Insurance-and-savings/Topics-andissues/Personal-injury-claims/Support-for-Customers-with-Road-Traffic-Injuries-ABI-code (last accessed 10 November 2016).

${ }^{46} \mathrm{n} 1$ above, at [133], Lord Mance.

${ }^{47}$ This wording is used in Aviva's home insurance policy (49): http://www.aviva.co.uk/home/overview-of-benefits.html (last accessed 1 October 2016).

${ }^{48}$ n 35 above.

${ }^{49}$ ibid at [15].
} 
benefits will be forfeited if the insured 'engaged in any fraudulent conduct, or made any false statement relating to this insurance'. ${ }^{50}$ Household and other types of policy typically require the insured to produce proof of ownership, such as a receipt, but this merely restates the principle that it is for the claimant to prove the loss. A forged document may also mean the insurers are not liable because of a failure by the insured to comply with a condition precedent in the policy requiring notification of the loss, although, again, this does not reintroduce the fraudulent devices rule.

The other difficulty is that under the Insurance Act 2015, section 15(1), a policy term will be of no effect if it puts 'the consumer in a worse position as respects any of the matters' in section 12. That section provides remedies for fraudulent claims, and these do not now include fraudulent devices. In non-consumer insurance, section 11 states that where compliance with a term, other than a term defining the risk as a whole, would tend to reduce the risk of loss of a particular kind, or at a particular location, or at a particular time, the insurers will be liable if the insured shows that noncompliance could not have increased the risk of the loss that occurred. The Law Commissions did not intend this to be confined simply to warranties, envisaging that it would apply to any term, including conditions precedent, so its precise scope will depend on the particular term. On a broad view it might, therefore, apply to a fraudulent device clause, but this seems unlikely since 'risk' in section 11 refers to the risk of the insured loss occurring, whereas a fraudulent device clause would presumably be designed to protect the insurers from having to pay in the event of the failure by the insured to follow a particular process, such as not submitting false documents. In any event, the policy may contract out of section 11 where the insurers have taken 'sufficient steps to draw the disadvantageous term to the insured's attention before the contract is entered into' (s.17(2)), although that still leaves the difficulty of how to draft such a clause.

\section{FRAUD IN CLAIMS SETTLEMENTS: HAYWARD V ZURICH INSURANCE $\mathrm{CO}$}

The other recent Supreme Court appeal on insurance fraud involved the settlement of a claim under an employer's liability policy where the third-party victim had dishonestly misrepresented the extent of his injuries. Of course, the insured - and, therefore, the insurers - are not liable where the claim is entirely fraudulent; but at common law the third-party victim was entitled to genuine losses, even if these had been accompanied by dishonest claims, because the courts refused to extend the fraudulent claims rule outside insurance contracts, and here the lie related to the settlement of damages for tort. The law has been changed. The Criminal Justice and Courts Act 2015, section 57, obliges the court to dismiss a personal injury claim where the claimant has been 'fundamentally dishonest' in relation to his or her own claim, or a 'related claim', that is, in respect of a claim by another person arising from the same incident, except where this would produce 'substantial injustice'. Similarly, under qualified one-way costs shifting (Q.O.C.S.), a losing personal injury claimant is not liable for defence costs, except where the claim is found on the balance of probabilities to be fundamentally dishonest'. ${ }^{51}$ Requiring the dishonesty to be

\footnotetext{
${ }^{50}$ Zurich's home insurance policy (7): https://www.zurich.co.uk/en/personal/insurance/home (last accessed 6 October 2016).

${ }^{51}$ Civil Procedure Rules 44.14 and 44.16(1).
} 
fundamental should mean fraudulent, ${ }^{52}$ although an early decision in the county court on Q.O.C.S. suggested the issue might depend on the proportion of the claim affected by the dishonesty by drawing a contrast between something that was merely 'collateral' and something that went 'to the root of either the whole of his claim or a substantial part of his claim'. 53

Section 57 and Q.O.C.S. apply only where the claim concerns personal injury, and, while these are the bulk of liability claims, motor cases frequently involve property damage, so that, for this reason alone, other responses to fraud remain relevant.

Section 57 followed the decision in Fairclough Homes Ltd $v$ Summers,${ }^{54}$ in which the Supreme Court noted that where fraud emerges before the trial and taints the entire claim, an application can be granted to strike out for abuse of process if the misconduct is so serious that it would be an affront to the court to permit the claim to continue, but in the end severely restricted its use. ${ }^{55}$ This case involved an application after the trial. $\mathrm{S}$ lied before and during the trial about the extent of injuries resulting from an accident at work, claiming around $£ 800,000$. The court accepted that the fraudulent claims rule applied only to insurance contracts, ${ }^{56}$ which meant that, in spite of S's dishonesty, he was awarded almost $£ 89,000$ for genuine injuries. The insurers, therefore, sought to avoid any liability by an application to strike out, and supported this with arguments similar to those used in support of the fraudulent claims rule, namely, that because fraud is commonplace the entire award should be forfeited as a deterrent.

The Supreme Court held that a court could grant an application after the trial, but would only do so in a 'very exceptional case' ${ }^{57}$ where it was 'just and proportionate'. ${ }^{58}$ The court agreed with Mummery L.J. when he said, in Masood v Zahoor, ${ }^{59}$ that such an application was meant to stop the waste of precious resources, and once the trial had been completed this purpose was gone. The court should, therefore, dismiss the claim, or make an award. Lord Clarke agreed on the need to take 'reasonable steps' to deter fraud, but 'there is a balance to be struck', and, 'To date the balance has been struck by assessing both liability and quantum'. ${ }^{60} \mathrm{~S}$ had been badly injured and the lies meant the court was unwilling to credit his evidence on other aspects of the claim with an inevitable effect on the amount awarded. Lord Clarke thought the reduction was 'just and proportionate'.

The draconian step of striking a claim out is always a last resort, a fortiori where to do so would deprive the claimant of a substantive right to which the

\footnotetext{
${ }^{52}$ B. Dixon and J. McQuater, 'Fundamental dishonesty: guidance for practitioners' (2016) 3 JPIL 121, 122; P. Hurst, 'The new costs rules and practice directions' (2013) 32(2) CJQ 153, 155-156; Lords Hansard, (Committee) 23 July 2014, cols. 1258-71

${ }^{53}$ Gosling v Hailo, 2014 WL 3002771, 29 April 2014 (Cambridge CC) at [45], HHJ Moloney QC. The reasoning continues to be applied: Meadows v La Tasca Restaurants Ltd 2016 WL 04446344

(Manchester CC) at [17].

${ }^{54} \mathrm{n} 22$ above.

${ }^{55}$ [2009] EWCA Civ 650.

${ }^{56}$ Ul-Haq v Shah [2009] EWCA Civ 542 at [16] and [37]; Fairclough Homes Ltd v Summers, n 22 above, at [29].

${ }^{57}$ n 22 above, at [61], Lord Clarke.

58 ibid.

${ }^{59} \mathrm{n} 55$ above, at [73].

${ }^{60} \mathrm{n} 54$ above, at [50].
} 
court had held that he was entitled after a fair trial. It is very difficult indeed to think of circumstances in which such a conclusion would be proportionate. ${ }^{61}$

Lord Clarke pointed out that the court could take other actions, such as reducing interest on any award for time wasted because of the fraud. He also strongly endorsed the idea of bringing proceedings for contempt, which would normally result in imprisonment. ${ }^{62}$ Insurers may, however, see no commercial benefit in what can be a complex and expensive task of gathering evidence. Lord Clarke said that a fraudulent claimant might be penalised by an award of costs - and, of course, this is allowed by Q.O.C.S., which was introduced after this case. Yet, although he thought 'the prospect of such orders is likely to be a real deterrent', ${ }^{63}$ the insurers may not be able to enforce a costs award because the individual is unlikely to have sufficient resources (unless there is a damages award), and any conditional fee agreement will not cover fraud. Lord Clarke made little of these difficulties, concluding: 'It ... seems to us that it is in principle more appropriate to penalise such a claimant as a contemnor than to relieve the defendant of what the court has held to be a substantive liability. ${ }^{64}$ While the passing of section 57 shows that, at least in regard to personal injury claims, this was not the view taken by Parliament, Lord Clarke's remarks do highlight an issue that is often unacknowledged in the discussion of fraudulent claims: dismissing the claim for fraud means the defendant is excused from its contractual obligations, or, where the insurers stand behind a tortfeasor, the wrongdoer's tortious liability.

The Supreme Court issued judgment in the most recent case on fraud in settlements a mere seven days after Versloot. In Hayward v Zurich Insurance Co plc, ${ }^{65} \mathrm{H}$ claimed $£ 420,000$ following a back injury at work. The employer's liability insurers, Z, did not dispute the injury but had suspicions about its extent, and yet they settled - albeit for just under $£ 135,000$ - because they were not confident that there was sufficient evidence to convince a court. Six years later, further evidence emerged that $\mathrm{H}$ had exaggerated his injuries. $\mathrm{Z}$ sought to recover the payment, set aside the settlement and obtain damages for deceit. The trial judge set the settlement aside, but awarded $\mathrm{H}$ $£ 14,720$ because the fraudulent misrepresentation only rescinded the settlement and did not remove the right to damages. The Court of Appeal reversed that decision and reinstated the original settlement. Although the judges expressed some reluctance, they thought there was no authority for the view taken by the trial judge, and they gave priority to the public policy interest in encouraging settlements above that of deterring fraud.

The Supreme Court overturned this decision. Lord Clarke remarked:

I am not persuaded that the importance of encouraging settlement, which I entirely agree is considerable, is sufficient to allow Mr Hayward to retain moneys which he only obtained by fraud. ${ }^{66}$

\footnotetext{
${ }^{61}$ ibid at [49], Lord Clarke.

${ }^{62}$ South Wales Fire and Rescue Service v Smith [2011] EWHC 1749 (Admin).

${ }^{63} \mathrm{n} 54$ above, at [53].

${ }^{64}$ ibid at [61].

${ }^{65} \mathrm{n} 2$ above.

${ }^{66}$ ibid at [22], Lord Clarke.
} 
The insurers need not show they were induced to enter into the settlement because they believed the representations were true. It is sufficient that the misrepresentation was a material cause of $\mathrm{Z}$ entering the agreement. Although doubting $\mathrm{H}, \mathrm{Z}$ took the reasonable view that a judge might believe him. The false representation was intended to influence the insurers, "not necessarily by causing them to believe him, but by causing them to value his litigation claim more highly than it was worth' ${ }^{67} \mathrm{Z}$ did not have all the facts and acted to its detriment. Lord Clarke could not 'envisage any circumstance in which mere suspicion that a claim was fraudulent would preclude unravelling a settlement when fraud is subsequently established. ${ }^{68}$ Once the representation has been shown to be fraudulent, it is for the claimant to show it played no material part in the insurers' decision to settle, which will be difficult.

The decision has been generally welcomed by the insurance industry, although there has been concern that it might encourage multiple attempts to reopen settlement agreements where the insurers, for whatever reason, have become fixated on the idea that the claimant is fraudulent. ${ }^{69}$ Insurers might use this threat to harass claimants, but the court in Hayward clearly intended that settlements should be inviolable unless fraud could be shown and that is no easy task. This still leaves the difficulty of determining when the settlement can be challenged. Lies tend to come not singly but in battalions. If the insurers are aware of a fraud, such as the exaggeration of an injury, but decide to pay because of their view that, in spite of the lie, public sympathy will be with the victim (or, where the insured is a major brand, concern over its reputation may create pressure to settle), can the settlement be reopened if a different lie is discovered of which the insurers knew nothing at the time? Presumably, the court would allow this because the representations are looked at separately. There might be an argument that there was no reliance because the insurers were willing to pay, irrespective of fraud, although, perhaps, the accumulation of frauds would make a difference.

\section{THE ROLE OF THE CIVIL LAW IN FRAUD}

Insurance fraud has received a lot of attention in the last few years. There have been high-level inquiries, including the Insurance Fraud Taskforce, which reported in $2016,{ }^{70}$ and the industry funds a fraud unit within the City of London Police. In Versloot and Hayward, the Supreme Court endorsed the fraudulent claims rule, as did the English and Scottish Law Commissions and Parliament in the Insurance Act 2015, and the approach taken in that rule has been extended by the Criminal Justice and Courts Act 2015.

The justification of the fraudulent claims rule is straightforward:

\footnotetext{
${ }^{67}$ ibid at [71], Lord Toulson.

${ }^{68}$ ibid at [48].

${ }^{69}$ J.M. Collins, 'Fraud - Several Bites of the Cherry?' (2016) at https://zenithpi.wordpress.com/2016/09/15/fraud-several-bites-of-the-cherry/ (last accessed 8 October 2016).

${ }^{70}$ Insurance Fraud Taskforce, Final Report (2016) at https://www.gov.uk/government/uploads/system/uploads/attachment_data/file/494105/PU1817_Insura nce_Fraud_Taskforce.pdf (last accessed 10 November 2016).
} 
It is important for the law to set out clear sanctions to deter policyholders from acting fraudulently. Although insurance fraud is a criminal offence, prosecutions are relatively rare, meaning that the civil law has an important part to play in deterring fraud ${ }^{71}$

If the insurers are not liable for losses that have not actually occurred or for exaggerated claims, irrespective of the honesty of the claimant, forfeiture of the genuine parts of the claim where there has been fraud amounts to punishment. This is inflicted primarily for the purpose of what criminologists call general deterrence, which means the decision about punishment is detached from the particular offence and people are punished to deter others. The lack of any evidence that such penalties are effective in deterring fraud did not greatly trouble the Law Commissions or the Supreme Court, even though this means the penalty becomes retributive. The issue was raised by counsel for the insurers during argument in Versloot, but the judges seemed to regard it as largely beyond discussion because of Parliament's endorsement of the fraudulent claims rule in the Insurance Act 2015 , section $12 .{ }^{72}$ In any event, Lord Sumption remarked:

Courts are rarely in a position to assess empirically the wider behavioural consequences of legal rules, the formation of legal policy in this as in other areas depends mainly on the vindication of collective moral values and on judicial instincts about the motivation of rational beings, not on the scientific anthropology of fraud or underwriting. ${ }^{73}$

This might be said to allow unscientific justifications - hunches. This works both ways. Lord Toulson rejected the argument put forward by the insurers that removing the fraudulent devices rule would affect behaviour by simply saying, 'I am sceptical about the idea that knowledge of this judgment will incentivise people with valid insurance claims to lie in support of their claims. ${ }^{.74}$

The other issue is whether imposing punishment for the purpose of general deterrence a proper objective for the civil law. Presumably, the deficiency in the criminal law, which the Law Commissions highlighted, ${ }^{75}$ is that there is not enough evidence to prosecute, so that the only way to punish those who are supposedly guilty of fraud is by applying the lower standard of proof used in the civil law. Popplewell J criticised the fraudulent claims rule as 'a form of penal non-damages', although, in part, this was because it had 'no parallel elsewhere in the common law. ${ }^{76}$ This awareness of the

\footnotetext{
${ }^{71}$ Law Commissions of England and Wales and Scotland, Reforming Insurance Contract Law: Issues Paper 7: The Insured's Post-Contract Duty of Good Faith, at paras 2.1-2.6; available at http://www.lawcom.gov.uk/wp-content/uploads/2015/06/ICL7_Insureds_Duty_of_Good_Faith.pdf (last accessed 1 October 2016).

${ }^{72}$ Sadly, this was the case even though the authors' earlier paper was (with others) cited to the court (https://www.supremecourt.uk/watch/uksc-2014-0252/160316-am.html) (last visited 10 November 2016): see P.J. Rawlings and J.P. Lowry, n 5 above, 98.

${ }^{73} \mathrm{n} 1$ above, at [10], Lord Sumption.

${ }^{74}$ ibid at [108], Lord Toulson.

${ }^{75}$ Law Commissions of England and Wales and Scotland, Insurance Contract Law: Business Disclosure; Warranties; Insurers' Remedies for Fraudulent Claims; and Late Payment, (Law Com. No 353/Scots Law Com No 238), at para.21.3, available at http://www.lawcom.gov.uk/wpcontent/uploads/2015/03/lc353_insurance-contract-law.pdf (last accessed 10 November 2016). ${ }^{76} \mathrm{n} 16$ above, [168]. This criticism was repeated to the Law Commissions by six judges of the commercial court including Christopher Clarke J: Law Commissions of England and Wales and
} 
unique nature of the rule did underpin the Supreme Court's decision to limit its scope because, as Lord Sumption put it, 'the law of insurance is concerned more with controlling the impact of a breach of good faith on the risk than with the punishment of misconduct. ${ }^{77}$ The proper role of the civil law was also considered in another appeal decided in a very busy July 2016 when the Supreme Court allowed the restitution of funds advanced for an illegal purpose that had never been carried out. Lord Neuberger said, 'it is for the criminal law, not the civil law, to penalise a party or parties for entering into and/or performing a contract with an illegal component. ${ }^{78}$ Lord Sumption agreed: 'although rules of civil law might have a punitive effect, this was no part of their purpose. ${ }^{79}$ Doubtless, the fraudulent claims rule was fresh in his mind because he was careful to add that there were limited exceptions to this general principle.

While the Supreme Court has narrowed the definition of the fraudulent claims rule, this rule (or its siblings) has made advances elsewhere. In Hayward, the aim of deterring fraud was given priority over the public interest in finalising settlements; the Insurance Act 2015 cemented in place, and, arguably extended, the remedies for insurance fraud; and the Criminal Justice and Courts Act established a quasifraudulent claims rule in all personal injuries cases. Why, one might ask, stop there? Yet, even if one ignores problems with the figures used to support assertions about the increase in insurance fraud, ${ }^{80}$ there remains the blurring of the boundary between the civil law and the criminal law. Of course, any criticism of a tougher line on fraud might seem ill placed and is not likely to be well received in insurance or law enforcement circles, but it is surely worth pausing to consider whether it is appropriate to use the civil law to impose what are in effect fines (the loss of genuine claims) without being required to prove the facts beyond all reasonable doubt because of the ease with which such penalties may be rolled out into other areas.

Scotland, Reforming Insurance Contract Law: Issues Paper 7: The Insured's Post-Contract Duty of Good Faith, at paras 2.13; available at http://www.lawcom.gov.uk/wpcontent/uploads/2015/06/ICL7_Insureds_Duty_of_Good_Faith.pdf (last accessed 9 October 2016).

${ }^{77} \mathrm{n} 1$ above, at [36], Lord Sumption.

${ }^{78}$ Patel $v$ Mirza [2016] UKSC 42 at [184]

${ }^{79}$ ibid at [230].

${ }^{80}$ P.J. Rawlings and J.P. Lowry, n 5 above, 115-117. 